\title{
INTRODUCING STEM DESIGNATED PROGRAM OF STUDY IN INFORMATION TECHNOLOGY - A CASE STUDY
}

\author{
Azad I. Ali, Indiana University of Pennsylvania, azad.ali@iup.edu
}

\begin{abstract}
Academic departments at colleges and universities often face situations that require them to update their curriculum. They may consider different aspects for what courses to include in their updated program and they follow certain protocols in order to update the old curriculum and institute the new changes. These protocols are often lengthy, time consuming and subject to bureaucratic procedures that need to be followed. Different reasons compel departments to start lengthy procedures like these. Enrollment decline in the program could make such curriculum updates more urgent and the department may resort to make significant updates to their curriculum to reverse the enrollment downturn. This paper explains about updating curriculum at time of enrollment decline. It illustrates the efforts of one Information Technology (IT) program in updating their program. Faculty members and administrators at the department worked to institute curriculum changes that are aimed at reversing the trend of enrollment decline. To respond to this enrollment downturn, the department suggested introducing a STEM designated program in Information Technology. This paper explains the efforts by this department in introducing a STEM designated program.
\end{abstract}

Keywords: STEM, Updating IT Programs, STEM Designation, STEM Programs

\section{INTRODUCTION}

Information technology (IT) academic departments are no stranger to curriculum update. IT departments often update their curriculum for different reasons such as responding to market demand, to changing technologies used, to align with faculty experience or to include totally new technologies (Khan \& Law, 2015). However, at times of dropping enrollment, curriculum updates take a critical stage. The question that may be repeated among the department personal is "how to update curriculum so to reverse the enrollment decline and help to bring more students into the program". This was the focus of an IT department that faced the downturn in enrollment. After long discussions about what to do about the downturn of enrollment, the department decided to introduce a STEM designated program. During the discussion about the curriculum, the faculty members at the department focused on the following four points within updating the curriculum:

- Whether to include a programming course or not in the new IT program

- Whether to include a database course or not in the IT program

- What new courses to include in the program and which existing courses to remove?

- $\quad$ Type of a degree that will be offered from this new program (Whether it will be a Bachelor of Science, Bachelor of Art, a major, a track or any others).

The remainder of this paper is divided in the following sections:

- $\quad$ The first section reviews literature and explains about STEM jobs and STEM education. It elaborates on reasons that compel departments to introduce STEM designated program and steps to follow to gain this designation

- $\quad$ The paper then reviews literature and elaborates on the four factors that were dominant in the discussion among members of the department for the curriculum update.

- $\quad$ It then explains about our department and how we followed numerous steps to update our curriculum and introduce the new STEM designated program - the Bachelor of Science in Information Technology.

- $\quad$ The last section provides a summary of the paper and suggestions for future research 


\section{LITERATURE REVIEW}

The term STEM is often repeated at different levels in reference to education and employment opportunities in four different fields: Science, Technology, Engineering and Mathematics. The discussion about STEM intensified and took higher levels at the federal and congressional level for three reasons:

1- The job growth from STEM fields of study expected to be going at a higher rate than the average of growth in other fields of study (Wasem, 2012). This creates a gap in the demand for people trained in STEM fields or to work in STEM related jobs.

2- Colleges and academic institutions are not graduating enough students to fill this gap in STEM workers. This lack of enough training in STEM education may extend this gap and shortage of STEM workers.

3- The gap and shortage of STEM workers will make our economy more dependent on importing labors from overseas, thus make our economy dependent on outside actors (Gonzalez, Kuenzi, 2012)

4- This dependency on foreign labor market creates another level of issues that need to be dealt with specifically issues about visas, allowing foreign workers to stay in the US any many other related issues

Another complexity that is added in this discussion is about the many glowing predictions of the future of STEM job market for the foreseeable future. Vilori (2014) best illustrates this glowing prediction of the STEM job market:

The future of the economy is in STEM," says James Brown, the executive director of the STEM Education Coalition in Washington, D.C. "That's where the jobs of tomorrow will be." Data from the U.S. Bureau of Labor Statistics (BLS) support that assertion. Employment in occupations related to STEM-science, technology, engineering, and mathematics-is projected to grow to more than 9 million between 2012 and 2022. That's an increase of about 1 million jobs over 2012 employment levels (p. 3).

\section{STEM Job Numbers Compared}

There is a fact that cannot be disputed in the employment field that there is a gap between what STEM job market requires and what our academic institutions are producing in terms of people with STEM skills. This denotes that academic institutions are not producing enough talents to fill this gap. The gap is expectedly to widen as more jobs in STEM fields are created (Stevenson, 2014).

To further illustrate the increasing demand for STEM trained workers, we searched the U.S. Bureau of Labor Statistic (or BLS) web site (www.bls.gov) to find statistics and predictions of jobs in STEM field. The BLS issues reports about predictions of the job market for ten-year period. The output is called "Occupational Outlook Handbook" and it reports different tables comparing one group of jobs with the other overall demand for jobs. Table 1 below shows the job predictions between 2018 and 2028 for STEM and for all occupations.

Table 1 - Employment Job outlook 2018-2028

source U.S. Bureau of Labor Statistics (www.bls.gov)

\begin{tabular}{|l|r|r|r|r|r|}
\hline \multirow{2}{*}{ Occupation Category } & \multicolumn{2}{|c|}{ Employment } & \multicolumn{2}{c|}{ Change 2018-2028 } & \multirow{2}{*}{$\begin{array}{l}\text { Median annual } \\
\text { wage (2018) }\end{array}$} \\
\cline { 2 - 5 } & $\mathbf{2 0 1 8}$ & $\mathbf{2 0 2 8}$ & Number & Percent & \\
\hline Total, all occupations & $161,037.70$ & $169,435.90$ & $8,398.10$ & 5.2 & $\$ 38,640$ \\
\hline STEM Occupations & $9,708.30$ & $10,566.80$ & 858.5 & 8.8 & $\$ 84,880$ \\
\hline
\end{tabular}

Table 1 above shows two trends in regarding to STEM jobs: First, the job market for STEM occupations is increasing at a faster rate than non-STEM occupations, and second, the annual wage for STEM occupations is substantially higher than non-STEM occupations. 


\section{Issues in Information Systems}

Volume 21, Issue 1, pp. 213-226, 2020

While the above table represent good news for many in STEM occupations, but there is a discrepancy between what market demands of STEM skills and what academic institutions produce in term of STEM trained talents. Different issues emerge from this discrepancy between what the market demands and what academic institution produce in STEM trained talents. The core of the problem is that it needs to be addressed at the level of STEM education.

\section{STEM Education}

The Congressional Research Service (CRS) issued reports to the US congress addressing the issue of STEM education (Ggranovskiy, 2018; Gonazalex \&Kuenzie, 2012, Wasem, 2012). The reports explain the need of the market for STEM trained workers and clarified what it means about STEM education. One of the explanations is listed below:

The term STEM education refers to teaching and learning in the fields of science, technology, engineering, and mathematics. It typically includes educational activities across all grade levelsfrom pre-school to post-doctorate-in both formal (e.g., classrooms) and informal (e.g., afterschool programs) settings. Federal policymakers have an active and enduring interest in STEM education, and the topic is frequently raised in federal science, education, workforce, national security, and immigration policy debates (Granovskiy, 2018, p. 1).

A different report issued by the Alliance For Science \& Technology Research in America (ACT, 2017) to assess STEM education in the US in terms of where we are and what we can do. The report noted about the status of STEM education and stated: "It is difficult to admit, but the United States is a STE-deficient nation". The report continued in their assessment and talked about three facts that are commonly understood among stakeholders in the STEM education issues:

- $\quad$ Fact \#1: Workers in the STEM fields are in high demand

- Fact \#2: The number of STEM occupations in the U.S. will grow by 8.9 percent between 2014 and 2024

- Fact \#3: Policy makers at all levels of government are emphasizing the importance of educating student for STEM-related jobs

- Fact \#4: not enough students are equipped for STEM opportunities

Taking the last fact above and translating it into a different format, could mean one of two points: not enough students are interested in STEM fields of study, or not enough programs are available to teach students STEM related skills. In most cases, it could mean both points.

Blackely and Howell (2015) issued a report that addresses these two-specific points. The authors noted through their investigation of the years of dealing with STEM related issued facts that leads to the belief that efforts are excreted at different levels to offer programs that provide STEM training, but the interest still lags behind. Glancey and Moore (2013) on the other hands suggested strategies to bolster STEM learning environment but the facts to the conclusion is that not enough U.S. students are interested in the STEM related fields of study. In the Congressional Research Service report, Granovskiy (2018) related STEM education to national prosperity and power and predicted that STEM education will continue to take the same importance as before and even more. The report then suggested excreted efforts be put in place to fill this gap of demand on STEM skills.

The efforts to increase interest in STEM education has been ongoing for some time, yet there is still a gap between what the market demands and what educational institutions produce in terms of graduates trained in these skills. What adds to this job is the gender difference in interest in STEM programs (women in particular are less interested in STEM programs). This gap is narrowed down by international students and their interest in STEM recognized programs Garnoviskiy \& Wilsom, 2017).

\section{STEM Programs and International Students}

Drawing from the Act(2017) that our county is a "STEM deficient nation" and taking it further, different reports suggested that our country does not take the leading role in terms of student achievement in STEM (Johnson, 2012). 
This eventually is translated into the lack of sufficient interest to apply to study in STEM related fields of study. Perna et al (2010) noted a significant point in this regard: The rate of bachelor's degree production in STEM field in the US is lower than that of many nations. A more relevant fact that can be noted here is the increasing interest of international students in applying for STEM degrees (Granoviskiy \& Wilson, 2017). This increase in interest is due in part to the advantages that international students gain for their visa status from applying and completing STEM degrees in the US.

When international students apply and come to the US for studying, they are given a non-immigrant visa that is called is the F1 visa type. The F1 visa status does not permit employment outside of the campus where the international students' study at (Wasem, 2012). International students are permitted to work on the campuses where they study. They are also permitted to work off campus in fields related to their study as to what is termed as Optional Practical Training (OPT) (Gonzalez \& Kuenz, 2012).

Optional Practical Training (OPT) is a period during which undergraduate and graduate students with F-1 status who have completed or have been pursuing their degrees for more than nine months are permitted to work towards getting practical training to complement their field of studies for a period of twelve months. The 12 months can be increased and allow the optional training to be extended by 17 additional months if the program they study at is at has a designation of STEM and that is what is termed as "STEM designated academic programs".

\section{STEM Designated Academic Programs}

An academic program is considered a "STEM designated" if it is given a code approved by the department of education as a STEM field of study. The name of the code is "CIP code" and is explained by the national center of education statistics ( https://nces.ed.gov/ipeds/cipcode/Default.aspx?y=56) as

The Classification of Instructional Programs (CIP) is a taxonomic coding scheme of instructional programs. Its purpose is to facilitate the organization, collection, and reporting of fields of study and program completions. The CIP was originally developed in 1980 by the National Center for Education Statistics (NCES) in the U.S. Department of Education, with revisions occurring in 1985, 1990, 2000, and 2010. The 2020 edition of the CIP (CIP-2020) is the sixth version of the CIP and presents an updated taxonomy of instructional program classifications and descriptions.

The CIP code is a six-digit code and is divided into two categories: 1) two-digit series, and 2) four-digit series. The two-digit series represent the most general groupings for programs. For example, Computer and Information Sciences are given code of 11, educational/instructional technology 13 and engineering technology as general field of study is given a code of 15 . There are 48 two-digit series. The four-digit series of the CIP code represents the subcategory or sub field of study. It shows different fields of study grouped under the general field of study represented in the two-digit presented in the six-digit code. For example, the following table presents sample of fields of study under the following three general categories:

- Computer and Information Science (Code 11)

- Educational technology (Code 13)

- Engineering Technology (code 15)

So, in order for a program to be considered "STEM Designated”, the department has to submit a program proposal to the department of education in their state, list the courses in the program and justifications and reasons to consider their program "STEM Designated". Among the explanation that need to be given in the proposal to the state is the type of employment that the new program is going to fulfill, the STEM jobs that the graduates that are likely to be trained for and other course explanation that shows the program is offering a STEM related field of study. 
Table 2 - Partial listing of CIP code - source www.bls.gov

\begin{tabular}{|c|c|l|}
\hline $\begin{array}{c}\text { CIP Code Two- } \\
\text { Digit Series }\end{array}$ & $\begin{array}{c}\text { 2010 CIP Code } \\
\text { (Six digit) }\end{array}$ & \multicolumn{1}{|c|}{ CIP Code Title } \\
\hline 11 & 11.0101 & Computer and Information Sciences, General \\
\hline 11 & 11.0102 & Artificial Intelligence \\
\hline 11 & 11.0103 & Information Technology \\
\hline 11 & 11.0104 & Informatics \\
\hline 13 & 13.0401 & Educational/Instructional Technology \\
\hline 13 & 13.0601 & Educational Evaluation and Research \\
\hline 15 & 15.0000 & Engineering Technology, General \\
\hline 15 & 15.0101 & Architectural Engineering Technology/Technician \\
\hline
\end{tabular}

\section{STEM and Other Recognition}

Oner, and Caprano (2016) asked the question "Is STEM Academy Designation Synonymous with Higher Student Achievement?". The answer to the question may be subject to wide discussion that are often disputed and contested. However, there are indicators that may lead to the conclusion that the answer to the question is "Yes" and that many associate STEM designated programs with higher achievement. Some facts that could support this answer may include the following:

- Higher rate of employment over the years could lead to easier path of job finding among graduates of STEM programs

- $\quad$ Higher average salary may indicate a more superior performance as compared to other programs

Taken all the factors behind, STEM designation has in the past been favored by many and in particular students who have strong background in mathematics. So, taken this into consideration, it is expected that adding "STEM Designation" to a program will bring more attention to it, it can work as a marketing tool and to it may be used to draw more students into the program.

\section{Other Issues}

In our department dialogue for updating our curriculum, we discussed a few factors that we considered for inclusion in our proposed STEM Designated program. The discussion focused on the following four factors:

- Whether to include a programming course or not in the new IT program

- Whether to include a database course or not in the IT program

- What new courses to include in the program and which existing courses to remove?

- $\quad$ Type of a degree that will be offered from this new program

In this section we review literature regarding these factors that were discussed by our department regarding including courses in our proposed program.

\section{Programming Courses versus Not}

It has been long agreed on in the IT industry that teaching programming is a must for all IT majors (Bills \& Biles, 2005). However, the depth at which programming is taught for IT students is not agreed on. Advocates of teaching programming point to different advantages that students can gain from having exposure to programming 


\section{Issues in Information Systems}

Volume 21, Issue 1, pp. 213-226, 2020

fundamentals and practices. While most recently, there has been calls from different academics to limit the teaching of programming for IT majors. This group point to different drawbacks from teaching programming courses. These drawbacks can extend to affect the students and the department that teaches it. The newer move for IT is to consider it as a "programming less" major (Bills \& Canosa, 2007). Others most stress the difficulty in learning to program as noted below:

Coding the syntax of today's popular programming languages can be frustrating for students who are new to programming. To write a simple program in Java for example, you must add extra code just to get the program to print the famous "Hello World" to the screen. The program must be typed with the proper capitalization, pristine spelling, and the exact amount of curly braces, quotes, semicolons, brackets, and parenthesis in the correct order. How can we expect students to gain confidence with programming, if they are constantly receiving compiler errors that are preventing them from executing their programs? (Daly, 2011, p. 23).

This kind of difficulty lead to a lot of attrition among students taking programming courses for first time (or what is termed as First Programming Course). Ali and Shubra (2010) noted that first programming course is among top causes of attrition in IT programs. Looking further and at times of making decisions to what courses to include in a program, it will be a good idea that we consult the standard curriculum that are developed for different fields of study.

In the information technology field, there are set of standard curriculum documents that are developed to establish some guidelines in specifying content for IT courses. Although these documents are not officially standardized in the field, but they are widely used and referenced in the IT field. Thus, these documents are considered quasi standard that programs reference when deciding on courses and programs to teach in the IT field. These documents are termed "Computing Curricula" and are developed by the Association of Computing Machine (ACM), and the Institute of Electrical and Electronics Engineers (IEEE-CS).

The latest of these "Computing curricula” documents is the IT2017 (Sabin, et al., 2017) for the information technology field of study. IT2017 explains the different IT domains, it divides the domains into three categories: Essential only, Essential + supplemental, Supplemental only. Figure 1 below shows the suggested domains of IT, their division among the three-coverage area and suggested percentage of coverage. 
Figure1: Suggested Domains of Study from IT2017

From the figure above, it can be noted that there is no suggested coverage of programming, instead it has changed to software fundamentals/software development and management domains. These domains have a suggested coverage of $4 \%$ of the recommended IT curriculum which is considered minimal in terms of coverage.

The Occupations Statistics Outlook draws picture that leads to same conclusion in terms of need for programmers in the job market. While the number of "computer programming" jobs are slowing down, but the jobs under the category of "software development" is increasing. The table below shows the contrast among these jobs:

Table 3: Job comparison 2018 thru 2029 for programming jobs. Source: www.bls.gov

\begin{tabular}{|l|c|c|c|c|}
\hline \multicolumn{1}{|c|}{ Job Title } & Jobs in 2018 & Jobs in 2028 & Percentage difference & \# Jobs Increase \\
\hline Software developers & $1,365,500$ & $1,649,600$ & $21 \%$ & 284,100 \\
\hline $\begin{array}{l}\text { Computer } \\
\text { Programmer }\end{array}$ & 250,300 & 232,300 & $-7 \%$ & $-17,900$ \\
\hline
\end{tabular}

The focus of the category of software developers is not only on programming (as it sounds from the title), instead it focuses on software developers and management which involves more than just programming. This brings back to the stage the same question that started this section, do we need to have a programming course in IT program?

\section{Database Courses VS Not Including Database Course}

The subject of teaching database courses in IT programs is not without controversies, although these controversies are significantly fewer than programming courses for two reasons: First, courses dedicated to teach database are not typically placed in the first year or among the earlier courses taken, instead, they are taken later when students have more experience and are more capable of dealing with course challenges. Second, the teaching of database often 
does not have same issues of syntax and structure, instead the issues are related to the multi-step that are involved in dealing with databases and the delayed outcome from producing output. A helpful point for this study is to look for the job outlook for database jobs to find if there is a healthy outlook for these jobs to consider including or deleting them from the curriculum.

The job outlook statistics produced by the US Bureau of Labor Statistics predicts there will be a 9\% increase in the Database administrator jobs. The table below shows the prediction of jobs between 2018-2028 for the database administrators' jobs.

Table 4: Employment projection for database administrators, 2018-28 (Source www.bls.gov)

\begin{tabular}{|l|c|c|c|c|}
\hline Occupational Title & Employment 2018 & $\begin{array}{l}\text { Projected } \\
\text { Employment, 2028 }\end{array}$ & Percentage Change & Numeric Change \\
\hline $\begin{array}{l}\text { Database } \\
\text { Administrator }\end{array}$ & 116,900 & 127,400 & 9 & 10,500 \\
\hline
\end{tabular}

A 9\% increase could be considered healthy to justify keeping the teaching of Database courses in the suggested curriculum. However, looking at the IT2017 suggested topics of teaching in IT listed in figure 2 above, there is no suggestion to teach a database course at any of the three levels: That brings to the front the first arguments about whether to include database courses or not. This discussion intensifies, as there are more new areas emerged in the teaching of IT.

\section{Decision to Include New Courses}

Information Technology educators often contemplate on deciding new courses to their curriculum. The rapid changes in technology and the shifting market demand on specific skills add a new dimension to their decision. However, there are points that may need to be considered as guidelines for academic programs struggling with enrollment decline that helps to answer the question of what to include in new courses that are introduced in IT programs.

Ghannadian (2013) noted that "What Employers Want; What we Teach" in a reference to the influence of market demand on the courses taught. Smith and Ali (2018) were more direct in their recommendations by suggesting that responding to market demand will be key in reversing enrollment downturn. So, the points to understand is to keep any eye on the market demand, to gain understanding on the skills the market demands and design courses to respond to these demands.

However, to gain understanding of the job market need to be supported by solid data from reliable data sources. Government data sources are often considered reliable data sources and what they publish in terms of trend or outlook for job data can be taken with high degree of confidence.

The Occupational Outlook Handbook, a research publication that are issued by the U.S. Bureau of Labor Statistics lists the different occupations that are grouped together. We searched the web site for jobs in STEM designation. The search resulted in different categories, the most direct category that relates to our program is titled "Computer and Information Technology Occupations". https://www.bls.gov/ooh/computer-and-information-technology/home.ht. This category of occupations lists ten different occupation titles. Table 5 below shows the job titles in employment comparison between 2018 and 2028 in these job categories as listed in the Occupational Outlook Handbook. 
Table 5 - Comparing employment numbers 2018-2028. Source www.bls.gov.

\begin{tabular}{|c|c|c|c|c|}
\hline Occupational title & $\begin{array}{l}\text { Employment in } \\
2018\end{array}$ & $\begin{array}{c}\text { Projected } \\
\text { employment } 2028\end{array}$ & $\begin{array}{c}\text { Change 2018-2028 } \\
\text { percentage }\end{array}$ & Change number \\
\hline $\begin{array}{l}\text { Computer and } \\
\text { Information Research } \\
\text { Scientists }\end{array}$ & 31,700 & 37,000 & $16 \%$ & 5200 \\
\hline $\begin{array}{l}\text { Computer network } \\
\text { architects }\end{array}$ & 159,300 & 167,700 & $5 \%$ & 8,400 \\
\hline $\begin{array}{l}\text { Computer } \\
\text { programmers }\end{array}$ & 250,300 & 232,300 & $-7 \%$ & $-17,900$ \\
\hline $\begin{array}{l}\text { Computer support } \\
\text { specialists }\end{array}$ & 863,100 & 946,200 & $10 \%$ & 83,100 \\
\hline $\begin{array}{l}\text { Computer systems } \\
\text { analysts }\end{array}$ & 633,900 & 689,900 & $9 \%$ & 56,000 \\
\hline $\begin{array}{l}\text { Database } \\
\text { administrators }\end{array}$ & 116,900 & 127,400 & $9 \%$ & 10,500 \\
\hline $\begin{array}{l}\text { Information security } \\
\text { analysts }\end{array}$ & 112,300 & 147,700 & $32 \%$ & 35,500 \\
\hline $\begin{array}{l}\text { Network and computer } \\
\text { systems administrators }\end{array}$ & 383,900 & 402,100 & $5 \%$ & 18,200 \\
\hline Software developers & $1,365,500$ & $1,649,600$ & $21 \%$ & 284,100 \\
\hline Web developers & 160,500 & 181,400 & $13 \%$ & 20,900 \\
\hline
\end{tabular}

At the same time, the IT2017 curriculum guideline suggests ten different domains between essential only and supplemental. Table 1 below, contrasts the titles suggested by the job outlook and by IT 2017. So, in order to combine both data, we list in table 5 below both IT jobs listed by IT2017 and the Occupational Outlook data.

Table 6 - IT Domains and Occupational Job Outlook

\begin{tabular}{|c|c|}
\hline IT Domain suggested by IT2017 & BLS Job Outlook \\
\hline 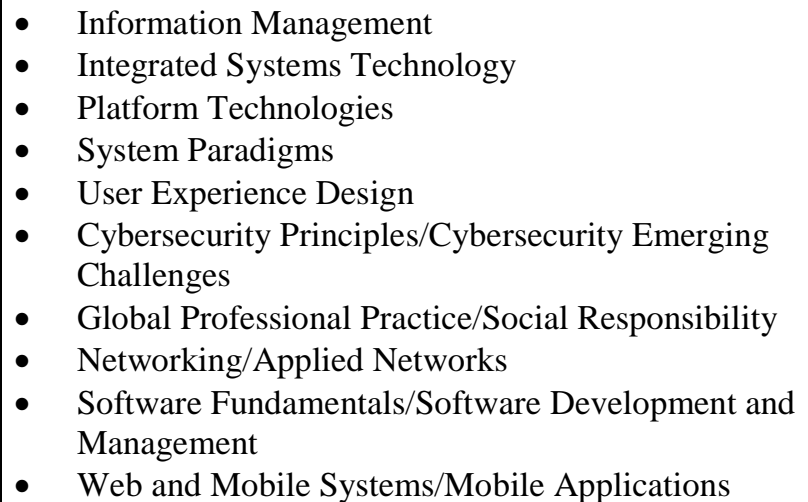 & $\begin{array}{ll}\text { - } & \text { Computer and Information Research } \\
& \text { Scientists } \\
\text { - } & \text { Computer Network Architects } \\
\text { - } & \text { Computer Programmers } \\
\text { - } & \text { Computer support specialists } \\
\text { - } & \text { Computer systems Analysts } \\
\text { - } & \text { Database administrators } \\
\text { - } & \text { Information security analysts } \\
\text { - } & \text { Network and computer systems } \\
& \text { administrator } \\
\text { - } & \text { Software developers } \\
\text { - } & \text { Web Developers }\end{array}$ \\
\hline
\end{tabular}


After comparing data from both the Occupational Outlook and the suggested domain in IT2017, the title of the job "Information Security Analyst" caught our eyes. The data suggested that the area of security is becoming $r$ is becoming popular and that there will be more demand on it in the future. The area of security could include network security, cybersecurity, information security and other similar fields. In order to further highlight the projected employment numbers, we list in table 7 below comparison of job outlook data between 2018 and 2028 for the Information Security Analyst job title

Table 7: Information Security Analyst job outlook statistics. Source www.bls.gov.

\begin{tabular}{|l|c|c|c|c|}
\hline $\begin{array}{c}\text { Occupational } \\
\text { Title }\end{array}$ & $\begin{array}{c}\text { Employment } \\
\mathbf{2 0 1 8}\end{array}$ & $\begin{array}{c}\text { Projected } \\
\text { Employment 2028 }\end{array}$ & $\begin{array}{c}\text { Percentage } \\
\text { Change }\end{array}$ & $\begin{array}{c}\text { Numeric } \\
\text { Change }\end{array}$ \\
\hline $\begin{array}{l}\text { Information } \\
\text { Security Analyst }\end{array}$ & 112,300 & 147,700 & 32 & 35,500 \\
\hline
\end{tabular}

The numbers about the job outlook for information security professionals is impressive. What is more impressive about this job title is when compared with other similar data from the computer technology occupations and total all occupations. Figure 2 below compares the job outlook for information security analyst, computer occupation and total occupation. The IT2017 lists security under a different title "Cybersecurity Principles/Cybersecurity Emerging Challenges", although the title could be different between both, but the focus is mainly similar: to discuss security challenges facing the IT field.

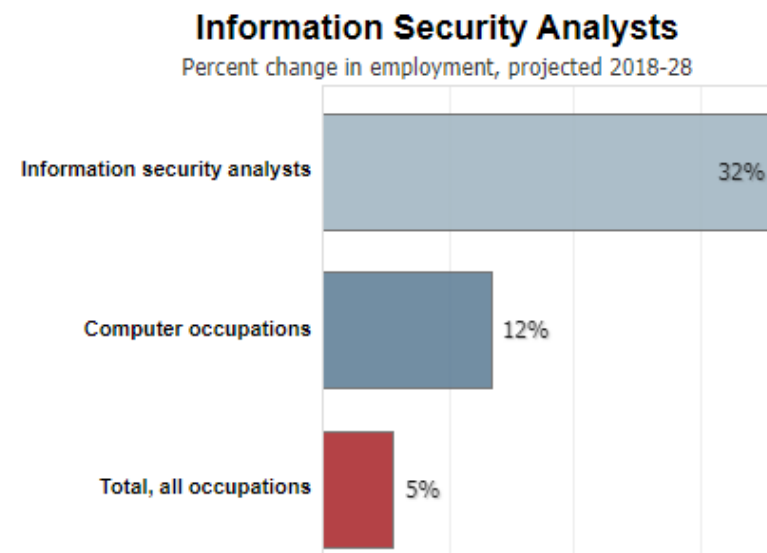

Figure 2: Information Security Analysts Job Projection - Source: https://www.bls.gov .

\section{IT Program in Different Contexts/Degrees}

To start a degree program, students need to take a minimum certain number of credits in order to obtain the degree sought. In a typical bachelor's degree, students must complete about 120 semester credits. The 120 credits are divided between liberal arts courses, college core courses, department core course and electives. Other questions emerge is what kind of baccalaureate degree are to be offered: Bachelor of Science, Bachelor of Arts, or any others.

The IT2017 curriculum suggests for IT degree program to teach about 45 credits in the field of study. The remaining courses could be taken from liberal arts, from other core courses or from other elective courses. It divides the 45 credits between essential IT domains (18 credits), Supplemental IT domains (9 credit) and IT electives (18 credits). Figure 3 below shows the division of courses suggested by IT2017.

While the number of courses is important, but he type of degree is important as well. Many parents look at subtle differences between B.Sc. and BA degrees to decide where to send their kids to study. However, when it comes to technical degrees like those covered in STEM, the focus is on choosing Bachelor of Science for the degree. 


\section{INTRODUCING IT PROGRAM AT OUR DEPARTMENT}

The department of Information Systems and Decision Sciences (ISDS) at Indiana University of Pennsylvania (IUP) has faced a situation that was discussed earlier in this paper. It faced steep decline of enrollment in the past several years as compared with previous years. The decline of enrollment reached a critical point that demanded from the department to act and necessitated a quick and decisive action regarding the curriculum.

Students enrolled in our ISDS department have to complete 120 semester credits to gain a baccalaureate degree in Management Information Systems. The credits taken start with general education courses to college core courses and then department required and elective courses. Out of the 120 semester credits, students have to take eight courses (24 credits) in our department deemed as our departmental required courses. Seven courses are required, and one course is controlled elective (the student have to take this elective course from a pool of elective courses are our department).

Our department offer a Bachelor of Science degree in Management Information Systems and the students can choose one of two tracks: Information Systems track and Information Technology track. The main difference between the two tracks is about programming courses. While the information systems track requires two programming courses, the IT track requires only one programming course. The remainder of this section explains the different aspects that were discussed in the department regarding updating the curriculum and introducing the STEM designated program of study in IT.

\section{Programming Course or Not}

This was subject up to discussion for a long time and led to making a decision to offer a "programming less" degree. Our students to a large degree do not like programming courses and it was a major reason for attrition in our program. The rapid changes of technology and the new emerging fields in IT made it less critical to teach programming. Areas like IT security, cloud computing, operating systems are deemed critical to study in IT majors. So, our decision was to eliminate the programming course and to replace it with another course like operating systems. We selected the operating systems course and suggested to include some scripting languages, to substitute for the coverage (though on a limited extent) of the deleted programming course.

\section{Database Course or Not}

The discussion about database course is less intense than what was discussed for programming courses. Although we had problems with our database course, but these problems were not as intense as the programming courses. Our database course is a junior level course, the code for it is IFMG390 and students at that level can handle ambiguity and difficult topics better earlier time in their study. Although there is a lot of other courses that can be included in the program, we thought that including a course like information security will be more helpful to the students. 


\section{What New Courses}

We decided on including two new courses and keep five of our existing courses. The first added course is in operating systems and the second is in IT security. The operating systems course was introduced because it complements our networking course. We decided to teach both topics in our new operating systems course: A desktop operating systems and a network operating system. We also decided to include scripting language in the course to recover some programming principles from the course we deleted from the program.

We decided to add a course in information technology security based on the market demand that were presented earlier in this study. There is a fact that cannot be ignored, the market needs a lot more graduates trained in IT security and offering course like this will likely attracts more students to the program. Additionally, we have a faculty in our department that is certified in cybersecurity, thus his experience will be a factor in the delivery of the course.

\section{IT Program in Different Contexts/Degrees}

Whether it will be a Bachelor of Science, Bachelor of Art, a major, a track or any others. We decided on Bachelor of Science, it is more compatible with our current Bachelor of Science in Management Information Systems. The difference here is that it will not be a track within a bachelor's degree, instead the degree will "Bachelor of Science in Information Technology". This is more consistent with the requirement for getting a STEM designated program and acquiring the SIP code for our new program. The state higher education department requires that the degree be titled "Bachelor of Science" in order to be STEM designated.

Table 8 below lists the courses that we required (department required courses) versus the old track that we had. The new courses are in italic and bold face to highlight what has been added. They replaced two existing courses (IFMG210 and IFMG390). We also have one controlled elective thus it raises the number of departments required courses to eight (or 24 credits). This is below the 45 credits suggested by IT2017 but this is a regulation that we have to follow because the liberal arts and required college courses will leave only eight courses for our department as "Department courses" or "Major Courses"

Table 8 - Departmental Courses Offered for Our Students

\begin{tabular}{|c|cl|}
\hline Initial Track Courses & \multicolumn{1}{c|}{ New B.Sc. IT Courses } \\
\hline IFMG210 Introduction to Front-End Business & & IFMG219 Computer Operating Systems \\
processing & Principles \\
OR IFMG230 Introduction to Back-end & IFMG250 Business Systems Theory \\
Business Applications & IFMG254 Computer Technology \\
IFMG250 Business Systems Technology & Virtualization \\
IFMG254 Computer Technology Virtualization & IFMG 352 LAN Design and Installation \\
IFMG 352 LAN Design and Installation & IFMG 360 Information Storage and \\
IFMG360 Information Storage and Management & Management \\
IFMG 390 Database Theory and Practice & IFMG 468 Information Technology \\
IFMG471 Data Center and Cloud Computing & Security \\
& & IFMG 471 Data Center and Cloud \\
& & Computing \\
\hline
\end{tabular}

\section{SUMMARY}

This study started after steep downturn trend in enrollment in the program of an IT department. The paper started by explaining the intention of the department to develop a STEM designated program in our IT department. It explained about STEM program, STEM education, the effect of international students and what does it mean to be "STEM Designated" program. The paper then reviewed literature about the four main topics of discussion that were dominant during our discussion of the new program. 


\section{Issues in Information Systems}

Volume 21, Issue 1, pp. 213-226, 2020

While the paper explained the points above, it predicted that introducing a STEM designated program will help to revise the downturn of enrollment. It is yet to be known whether this goal from the introduction of the program will be achieved and that enrollment will increase from introducing this STEM designated program. It is therefore reasonable to suggest a follow-up on whether the program achieved this goal or not. The suggested study will address the different characteristics that were cited as the reason for introducing the new STEM designated program.

\section{REFERENCES}

ACT(2017). STEM Education in the U.S.: Where We are and What We Can Do. Retrieved from https://www.usinnovation.org/reports/stem-education-us-where-we-are-and-what-we-can-do

Ali, A., \& Shubra, C. (2010). Efforts to reverse the trend of enrollment decline in computer science programs. Issues in Informing Science and Information Technology, 7, 209-224.

Bills, D. P. \& Biles, J. A. (2005). The role of programming in IT. Proceedings of the 6th conference on Information technology education, 43-49. Retrieved December8th, 2010 from ACM digital library http://www.acm.org/dl

Bills, D. P. \& Canosa, R. L. (2007). Sharing introductory programming curriculum across disciplines. Proceedings of the 8th ACM SIGITE conference on Information technology education, 99-106.

Daly, T. (2011, May). Minimizing to Maximize: An Initial Attempt At Teaching Introductory Programming Using Alice. Journal of Computer Science in Colleges, 26(5), 23-30.

Ghannadian, F. F. (2013). What employers want, what we teach. BizEd, 12(2), 40-44.

Glancy, A. W., \& Moore, T. J. (2013). Theoretical foundations for effective STEM learning environments.

Gonzalez, H. B., \& Kuenzi, J. J. (2012, August). Science, technology, engineering, and mathematics (STEM) education: A primer. Washington, DC: Congressional Research Service, Library of Congress.

Granovskiy, B. (2018). Science, Technology, Engineering, and Mathematics (STEM) Education: An Overview. CRS Report R45223, Version 4. Updated. Congressional Research Service.

Information Technology 2008 Curriculum Guidelines for Undergraduate Degree Programs in Information Technology (2008). Retrieved July 10, 2011 from ACM Digital Library http://www.sigite.org/

Johnson, C. C. (2012). Implementation of STEM education policy: Challenges, progress, and lessons learned. School Science and Mathematics, 112(1), 45-55.

Khan, M. A., \& Law, L. S. (2015). An Integrative Approach to Curriculum Development in Higher Education in the USA: A Theoretical Framework. International Education Studies, 8(3), 66-76.

Öner, A. T., \& Capraro, R. M. (2016). Is STEM academy designation synonymous with higher student achievement?. Education \& Science/Egitim ve Bilim, 41(185).

Sabin, M., Alrumaih, H., Impagliazzo, J., Lunt, B., Zhang, M., Byers, B., ... \& Veer, G. (2017). Curriculum guidelines for baccalaureate degree programs in information technology. Technical Report.

Smith, D. T., \& Ali, A. I. (2018). A welcomed reversal in computer science enrollments: Analysis of contributing factors and recommendations to sustain the growth. Online Journal of Applied Knowledge Management (OJAKM), 6(1), 119-137. 


\section{Issues in Information Systems}

Volume 21, Issue 1, pp. 213-226, 2020

Stevenson, H. J. (2014). Myths and Motives behind STEM (Science, Technology, Engineering, and Mathematics) Education and the STEM-Worker Shortage Narrartive. Issues in Teacher Education, 23(1), 133-146.

Vilorio, D. (2014). STEM 101: Intro to tomorrow's jobs. Occupational Outlook Quarterly, 58(1), 2-12.

Wasem, R. E. (2012, November). Immigration of foreign nationals with Science, Technology, Engineering, and Mathematics (STEM) degrees. Congressional Research Service, Library of Congress. 